Charles Darwin's Barnacle and David Bowie's Spider 
This page intentionally left blank 


\title{
CHARLES DARWIN'S
}

\section{BARNACLE AND}

\section{DAVID BOWIE'S SPIDER}

\author{
HOW SCIENTIFIC NAMES \\ CELEBRATE ADVENTURERS, \\ HEROES, AND EVEN A FEW \\ SCOUNDRELS \\ STEPHEN B. HEARD
}

WITH ILLUSTRATIONS BY EMILYS. DAMSTRA

Yale

UNIVERSITY PRESS

New Haven and London 
Published with assistance from the Louis Stern Memorial Fund.

Copyright (C) 2020 by Stephen B. Heard.

Illustrations (C) Emily S. Damstra, except as noted.

All rights reserved.

This book may not be reproduced, in whole or in part, including illustrations, in any form (beyond that copying permitted by Sections IO7 and 108 of the U.S. Copyright Law and except by reviewers for the public press), without written permission from the publishers.

Yale University Press books may be purchased in quantity for educational, business, or promotional use. For information, please e-mail sales.press@ yale.edu (U.S. office) or sales@yaleup.co.uk (U.K. office).

Set in Gotham and Adobe Garamond type by IDS Infotech Ltd., Chandigarh, India.

Printed in the United States of America.

ISBN 978-0-300-23828-o (hardcover : alk. paper)

Library of Congress Control Number: 2019947766

A catalogue record for this book is available from the British Library.

This paper meets the requirements of ANSI/NISO Z39.48-1992

(Permanence of Paper).

10987654321 